\title{
THE DIFFERENCE IN FLEXIBILITY OF LUMBAR JOINTS BEFORE AND AFTER YOGA GYMNASTICS IN THE INTEGRATED HEALTH CENTER (POSYANDU) YUSWO WIDODO SURABAYA \\ Gracelia Alverina $^{1)}$, Inge Wattimena ${ }^{2)}$, Yudita Wulandari ${ }^{3)}$
}

\begin{abstract}
Introduction: Indonesian Ministry of Health Research (2017) stated that since 2000 the percentage of older people is above 7\%and predicts that the population of Indonesian seniors will continue to increase. The elderly will undergo a gradual decline in physical and mental capacities, one of which is a decrease in lumbar joints flexibility. It can be prevented by exercising. One of the suitable exercise that can be done is yoga.

Purpose: To analyze the flexibility of lumbar joints in the elderly before and after yoga exercises.

Method: this study is a pre-experimental study with one group pretest-posttest design approach. The sampling techniques used in this research was non-probability sampling method i.e., purposive sampling with a sample of 35 people. Elderly flexibility was measured using the sit and reach test scale.

Result: The flexibility of lumbar joints in thirty-five elderly as subjects before yoga on the first day and after the yoga on the last daywas measured using a meter band, and the result showed 27 older people with increased flexibility, six older people with decreased, and two people who have no change. The Results obtained a significant difference between before and after the yoga exercise program $(\mathrm{P}=0.00)$.

Conclusion: There is a difference in the flexibility of lumbar joints before and after yoga gymnastics in the elderly at Integrated Health Center (Pos Pelayanan Terpadu in Indonesian or Posyandu) Yuswo Widodo Surabaya, with better flexibility after yoga exercise. This favorable condition might minimize the probability risk of musculoskeletal injury.
\end{abstract}

Keyword: Yoga, Lumbar Joint Flexibility, Sit and Reach Test

\footnotetext{
${ }^{1)}$ Student of Faculty of Medicine, Widya Mandala Catholic University Surabaya, Jl. Kalisari Selatan No. 1 Surabaya Email : Gracealverina@gmail.com

2) Public Health Department, Faculty of Medicine, Widya Mandala Catholic University Surabaya, Jl. Kalisari Selatan No. 1 Surabaya

${ }^{3)}$ Internal Medicine Department, Faculty of Medicine, Widya Mandala Catholic University Surabaya, Jl. Kalisari Selatan No. 1 Surabaya
} 


\section{INTRODUCTION}

Under Law No. 13 of 1998 on elderly welfare, it is mentioned that the elderly is a person who reaches the age of 60 years old, and older. ${ }^{1}$ Older people are referred to as seniors. data from the Republic of Indonesia statistics Agency (2017), mentioned that in 2017 , there are 23 million (8.97\%) older people in Indonesia. $^{2}$ The results of the Indonesian Ministry of Health Research (2017) stated that since 2000 the percentage of older people is above $7 \%$. This statistic means that Indonesia begins to enter into an aging population group. Indonesian Ministry of Health predicted that the population of Indonesian seniors in 2020 (27.08 million), the year 2025 (33.69 million), the year 2030 (40.95 million), and the year 2035 (48.19 million). There are three Indonesian provinces with the highest percentage of elderly, Yogyakarta (13.04\%), Central Java 4.31 million (10.40\%), and East Java 4.60 million (10.34\%).

The elderly group will experience a process called the aging process. According to WHO, the elderly will experience a gradual decline in physical and mental capacities, increased risk of illness, and eventual death. ${ }^{3}$ One of them is decreasing flexibility. ${ }^{4}$ Flexibility is the ability to move through a full space of motion. In the elderly, one part of the body that has decreased flexibility is the lumbar joint.

Lumbar joints tend to change structures that can reduce the elasticity of the tissues. If left in a long time, then it can lower the flexibility. This causes the elderly to experience complaints of obstacles in the movement of the back, challenging to bend, lower back pain during activity. ${ }^{5}$ Limitations of the elderly in conducting activities can lower the quality of life.

Moreover, it can also increase the risk of back injuries. According to the Indonesian Ministry of Health Research/Riskesdas (2013), the national prevalence of back injuries was 8.2 percent. Comparison of results Riskesdas 2007 with Riskesdas 2013 showed a tendency to increase the prevalence of injuries from 7.5 percent to 8.2 percent. $^{6}$

One of the way to prevent this risk is through exercise. The sport that is recommended for the elderly is low impact, such as yoga gymnastics. Yoga Gymnastics is a relatively safe sport for the elderly. Regular yoga gymnastics can reduce stress, improve posture, increase strength, endurance, and flexibility. Yoga Gymnastics is a stretching exercise aimed at maintaining the elasticity of tissues to improve the activity of movement in the elderly. $^{7}$

Based on the initial survey 
conducted in March 2019 in Posyandu Yuswo Widodo, there are 53 older people. the elderly's most common complaint is a disturbance to the back. ${ }^{7}$

Previously there was research on yoga gymnastics and flexibility of lumbar joints by Anisa Nur in Surakarta with the result of the effect of yoga gymnastics on the flexibility of lumbar joints in the elderly. However, there has been no research on it in Surabaya.8 Therefore, we are interested in studying the differences in flexibility of lumbar joints in the elderly before and after yoga gymnastics in Posyandu Yuswo Widodo.

\section{METHOD}

This research is a quantitative study; the research method used in this research is pre-experimental with one group approach pretest-Posttest design. ${ }^{9}$ In this study, the population used was the elderly aged $\geq 60$ years old in Posyandu Yuswo Widodo.

The samples in this study were elderly who are in Posyandu Yuswo Widodo, which meet the criteria of inclusion and exclusion and in the period of research that started in July to August 2019, two times a week, with the 60minute duration of each exercise for the next eight weeks.

The sampling techniques in this study used non-probability sampling methods, i.e., purposive sampling, where we took all populations that met the inclusion criteria. The inclusion criteria of this study are the elderly who are $\geq 60$ years old and have never participated in yoga gymnastics, willing to be the subject of research and sign informed consent, can follow the instructions provided and cooperative, while the exclusion criteria are being sick or sore on musculoskeletal. The drop-out criteria are not to following the yoga gymnastics up to four times. This study's procedure is that respondents' the flexibility of the lumbar joints was measured before the yoga gymnastics procedure with the meter, then again after performing the yoga gymnastics for 16 times.

\section{RESULTS}

The research results based on the essential characteristics of the research subject consisting of gender, age, level of education, and occupation. The respondents in Posyandu Yuswo Widodo were 35 women. the most common age group was the age range of 60-74 years old as many as 31 respondents with a percentage of $88.6 \%$, While elderly with age range of 75-85 years was as many as four people with a percentage of $11.4 \%$. The average age of respondents in Posyandu Lansia Yuswo Widodo Surabaya was \pm 69.03 years old. the level of 
education in 35 respondents were: one educated person not in school with a percentage of $2.9 \%$, five people educated up to elementary school with a percentage $14.3 \%, 22$ people educated to senior high school with percentage $62.8 \%$, and two had higher education degree with a percentage of $5.7 \%$.

From the results of flexibility examination of lumbar joints before and after yoga gymnastics based on age: respondents with an abnormal value of flexibility before yoga gymnastics (pretest) in the age range $60-74$ years old was one person $(2.85 \%)$, and none in age range 75-85 years old. Respondents with a value of normal flexibility after yoga gymnastics (post-test) in the age range of 60-74 years was 30 people $(82.8 \%)$, the age of $75-85$ years was 4 people $(11.42 \%)$.

The distribution of results from flexibility examination of lumbar joints before yoga gymnastics based on the level of education: normal flexibility is most among the high school educated 22 people $(62.8 \%)$, then undergraduate education amounting to two people (5.71\%), junior education for five people $(14.28 \%)$, and elementary school education three people (11.42\%). In contrast, abnormal flexibility is found only ampng participant with no school education, one person $(2.85 \%)$,.

flexibility change from before and after yoga gymnastics in the elderly: increased flexibility 27 people (77.14\%), stable two people (5.71\%), and decreased six people (17.14\%). Analysis of the flexibility of the lumbar joints before and after yoga gymnastics in the elderly using the statistic test Paired Sample T-Test obtained the value $\mathrm{P}=0.00$ smaller than $\alpha$ $=0.05$ which means that there is a significant difference between flexibility of lumbar joints before and after yoga gymnastics in elderly women at Posyandu Yuswo Widodo with greater flexibility in post-test conditions.

\section{DISCUSSION}

From the results of the study, there is a a significant difference between the flexibility of the lumbar joints before and after yoga gymnastics in the elderly in Posyandu Yuswo Widodo with greater flexibility on Post Test State. The results of the study by Annisa NR showed that there was an influence from yoga gymnastics for the flexibility of lumbar joints in the elderly. The pre-tests and post-test measurements of the sit and reach test with the value $P=0,003$, which means there is an influence from yoga gymnastics on the flexibility of lumbar joints.

Based on the Indonesian Ministry of Health in 2016, it is mentioned that the elderly is a person who reaches the age of 60 years and above. Elderly will experience an aging process, and with 
increasing age, the physiological function has decreased due to degenerative processes (aging), so that many noncontagious diseases appear in the elderly. ${ }^{10,11}$

One of the examples of physiological changes occurring in the elderly is the alteration of the musculoskeletal system due to reduced activity, or also often due to metabolic disorders or denervation of nerve muscles into atrophy. Degrading muscle conditions due to this inactivity can be solved by improving the lifestyle, one of them by exercising. However, degeneration due to metabolic diseases that interfere with the nerve is often irreversible, although the metabolic abnormalities are corrected. Decreased bone mass causes bones to become brittle and weak. The vertebral column is subjected to compression, causing high body decline. Most of the elderly undergo postural changes, decreased range of motion, and slow movements. Bone structure changes occur, where bones become weak and are easy to undergo fractures. Bone density decreases due to decreased estrogen (female) hormones. There is a decrease in collagen, thereby lowering ligament elasticity. Interference from the soft tissue function provides an effect on the joints mechanics. The stiffness of the back and neck also often occurs due to changes in the intervertebral discs. $^{12}$

Thus, it can lead to decreased flexibility of lumbar joints in the elderly. Therefore, the elderly need yoga gymnastics as an exercise that requires stretching from the muscles and joints, where the exercise combines static and passive stretching. Yoga gymnastics is an exercise or physical activity performed to maintain a range of joint motion (ROM).

From the results of the research, it can be concluded that there is a difference in the flexibility of lumbar joints before and after yoga gymnastics in the elderly in Posyandu Yuswo Widodo.

\section{CONCLUSION}

From the results of the study with the title "Difference in the flexibility of lumbar joints before and after yoga gymnastics at Posyandu Yuswo Widodo" which was held on 26 June-23 August 2019, with 35 people respondents, it can be concluded that there is a significant difference in the flexibility of lumbar joints before and after yoga gymnastics in woman elderly in Posyandu Lansia Yuswo Widodo Surabaya. This suggests that yoga gymnastics is beneficial to increase the flexibility of lumbar joints in elderly women. Thus, the risk of musculoskeletal injury in elderly women can be minimized 
due to the better results in the yoga gymnastics post-test.

\section{REFERENCES}

1. Kemenkes RI. Situasi dan analisis lanjut usia. Pusat data dan informasi 2014;67:43-45. Available from : https://doi.org/10.3200/EXPL.67.1.4 3-45

2. Kemenkes RI. Analisis lansia di Indonesia. Pusat data dan informasi 2017;1-2. Available from: www.depkes.go.id/download.php?fi le $=$ download/.../infodatin lansia 2016.pdf\%0A.

3. WHO. Aging and health. 2018;2. Available from: https://www.who.int/newsroom/fact -sheets/detail/ageing-and-health

4. Baptista H, Medeiros DO, Gil C, \& Araujo S De. Age related mobility loss is joint specific: an analysis from 6,000 flexitest results. 2017;2399-2407. Available from: https://doi.org/10.1007/s11357-0139525-z

5. Nurdianti D. Pengaruh pemberian latihan Mc kenzie terhadap perubahan fleksibilitas lumbal pada lansia di panti wreda dharma bakti Surakarta. Program studi fisioterapi fakultas ilmu kesehatan Universitas Muhammadiya Surakarta, 2017;(6):67-72. Available from http://eprints.ums.ac.id/49665/1/PD F\%20\%28NASKAH\%20PUBLIKA SI\%20PERBAIKAN.pdf

6. Kementerian Kesehatan Republik Indonesia 2013. Hasil riset kesehatan dasar kementerian RI 2013. Proceedings, annual meeting, air pollution control association. 2013;6:10. Available from: https://doi.org/1 Desember 2013

7. Pamungkas YI, Hartati E, Supriyono M. Efektifitas pemberian stretching terhadap di unit pelayanan sosial lanjut usia. Jurnal ilmu keperawatan dan kebidanan (JIKK). 2017;1-9. Available from: http://ejournal.stikestelogorejo.ac.id/ index.php/ilmukeperawatan/article/v iew/509/50

8. Nur A. Pengaruh yoga terhadap fleksibilitas punggung lanjut usia di sanggar senam rm 7 Colomadu. Surakarta. 2018;2-3. Available from

http://eprints.ums.ac.id/59197/8/NA SKAH\%20PUBLIKASI.pdf

9. Fitness AC \& Fitnesss test. Flexibility test sit and reach purpose procedure equipment. 2013;23-25 Available from: http://acsf.edu.au/pdf/Flexibility Te st Sit and Reach.pdf

10. Turkheimer E, Waldron $\mathrm{M}$. Peraturan menteri kesehatan Republik Indonesia nomor 25 tahun 2016 tentang rencana aksi nasional kesehatan lanjut usia tahun 20162019. Psychological Bulletin. 2019;126(1):21. Available from: https://doi.org/.1037//00332909.I26.1.78

11. Kementerian sekretariat Negara Republik Indonesia. Undang-undang nomor 13 tahun 1998 tentang usia lanjut. Undang - undang republik Indonesia No 13 Tahun 1998 tentang kesejahteraan Lansia. 2019;8. Available from: http://www.bpkp.go.id/uu/filedownl oad/2/45/438.bpkp

12. Martono $\mathrm{H}$, Kris P. Buku ajar Boedhi-Darmojo geriatri (ilmu kesehatan usia lanjut). 4th ed. Jakarta: Balai Penerbit FKUI. 2009;55-66 